\title{
Global regulation in Erwinia species by Erwinia carotovora rsmA, a homologue of Escherichia coli csrA : repression of secondary metabolites, pathogenicity and hypersensitive reaction
}

\author{
Asita Mukherjee, Yaya Cui, Yang Liu, C. Korsi Dumenyo \\ and Arun K. Chatterjee
}

Author for correspondence: Arun K. Chatterjee. Tel: +1 314882 2940. Fax: +1 3148820588.

Department of Plant Pathology, University of Missouri, Columbia, MO 65211, USA

\begin{abstract}
Our previous studies revealed that rsmA of Erwinia carotovora subsp. carotovora strain 71 suppressed the synthesis of the cell density (quorum) sensing signal $\mathbf{N}$-(3-oxohexanoyl)-L-homoserine lactone, the production of extracellular enzymes and tissue macerating ability in soft-rotting Erwinia species and that homologues of this negative regulator gene were present in other Erwinia species. Northern blot data presented here demonstrate that rsmA and rsmA-like genes are also expressed in soft-rotting and non-softrotting Erwinia spp. such as E. amylovora, E. carotovora subsp. atroseptica, E. carotovora subsp. betavasculorum, E. carotovora subsp. carotovora, E. chrysanthemi, E. herbicola and E. stewartii. A low-copy plasmid carrying rsmA of E. carotovora subsp. carotovora strain 71 caused suppression of antibiotic production in E. carotovora subsp. betavasculorum, flagellum formation in $E$. carotovora subsp. carotovora, carotenoid production in E. herbicola and $E$. stewartii, and indigoidine production in E. chrysanthemi. In E. amylovora, rsmA of $E$. carotovora subsp. carotovora suppressed the elicitation of the hypersensitive reaction in tobacco leaves and the production of disease symptoms in apple shoots, in addition to repressing motility and extracellular polysaccharide production. We conclude that rsmA homologues function as global regulators of secondary metabolic pathways as well as factors controlling host interaction of Erwinia species.
\end{abstract}

Keywords: Erwinia, motility, pathogenicity factors, global regulation, hypersensitive reaction

\section{INTRODUCTION}

The enterobacterial genus Erwinia contains plant-pathogenic and plant-associated bacteria that are capable of producing extracellular enzymes, polysaccharides, antibiotics or pigments (Chatterjee \& Vidaver, 1986; Starr, 1983; Vanneste, 1995). A number of regulatory genes have been identified in Erwinia that specifically control the production of extracellular enzymes (Barras et al., 1994; Collmer \& Keen, 1986; Kotoujansky, 1987), polysaccharides (Leigh \& Coplin, 1992; Roberts \& Coleman, 1991) and antibiotics (McGowan et al., 1995). Such specific regulatory systems are generally activated during lateexponential growth or early-stationary phase when bac-

Abbreviations: EPS, extracellular polysaccharide; HR, hypersensitive reaction; HSL, N-(3-oxohexanoyl)-L-homoserine lactone. teria reach high cell density, when experiencing nutrient limitation (starvation) or both. This growth-phase dependence suggests that production of extracellular enzymes and secondary metabolites such as antibiotics, pigments and polysaccharides may respond to a common regulator. Evidence supports the hypothesis that the cell density (quorum) sensing signal $\mathrm{N}$-(3-oxohexanoyl)-Lhomoserine lactone (HSL), or its structural analogues could be a component of such a regulatory system. It has been discovered that in Erwinia carotovora subsp. carotovora, HSL is required for the production of extracellular enzymes and an antibiotic as well as for pathogenicity (Bainton et al., 1992; Jones et al., 1993; Pirhonen et al., 1993). Also, many soft-rotting and non-soft-rotting Erwinia species are now known to produce HSL (Bainton et al., 1992; Beck von Bodman \& Farrand, 1995; Chatterjee et al., 1995; Cui et al., 1995; Jones et al., 1993; 
Pirhonen et al., 1993; Salmond et al., 1995; Williams et al., 1992; A. K. Chatterjee, unpublished results).

We recently identified a negative regulator gene, $r s m A$ of E. carotovora subsp. carotovora strain 71 (Chatterjee et al., 1995; Cui et al., 1995), which suppressed the synthesis of HSL, the production of extracellular pectate lyase (Pel), polygalacturonase (Peh), cellulases ( $\mathrm{Cel}$ ) and proteases (Prt), and pathogenicity in soft-rotting Erwinia species. This pleiotropic effect of RsmA, as well as extensive similarity between $\operatorname{rsm} A$ and $\operatorname{csr} A$ of Escherichia coli, and the occurrence of $r s m A$ homologues in all other enterobacterial species tested, led us to consider the possibility that $\operatorname{rsm} A$ or its homologues may function as global regulators in Erwinia. In this communication, we demonstrate that $r s m A$ homologues are normally expressed in Erwinia species, and that $r s m A$ of E. carotovora suppresses such diverse traits as the production of an antibiotic, pigments and extracellular polysaccharides (EPS), flagellum formation and motility, pathogenicity and elicitation of the hypersensitive reaction (HR).

\section{METHODS}

Bacterial strains, plasmids and media. Bacterial strains and plasmids used in this study are listed in Table 1. The strains carrying drug markers were maintained on LB agar containing appropriate antibiotics. The wild-type strains of Erwinia were maintained on yeast extract/glucose/calcium carbonate (YGC) agar.

The compositions of $\mathrm{KB}$ medium, LB medium, minimal medium, nutrient gelatin agar, and YGC agar have been previously described (Barras et al., 1987; Chatterjee, 1980; Chatterjee et al., 1995; Murata et al., 1990, 1991). Nutrient agar glycerol (NAG) medium was prepared according to Costa \& Loper (1994). For the detection of EPS production, nutrient agar supplemented with $1 \%(\mathrm{w} / \mathrm{v})$ galactose was used. When required, ampicillin and spectinomycin were supplemented at $50 \mu \mathrm{g} \mathrm{m}^{-1}$. Media were solidified by the addition of $1.5 \%(\mathrm{w} / \mathrm{v})$ agar, except soft $\mathrm{KB}$, which contained $0.4 \%(\mathrm{w} / \mathrm{v})$ agar.

Antibiotic assay. The procedure described by Costa \& Loper (1994) was utilized for the detection of antibiotic production. Briefly, cells of E. carotovora subsp. betavasculorum strain Ecb11129 harbouring the $\mathrm{RsmA}^{+}$plasmid $\mathrm{pAKC} 880$ or the cloning vector pCL1920 were patched on NAG medium supplemented with spectinomycin and incubated at $28^{\circ} \mathrm{C}$ for $48 \mathrm{~h}$. A culture of the test strain E. carotovora subsp. carotovora 193 harbouring pCL1920, grown to a Klett value of approximately $30\left(\mathrm{OD}_{600} 0.24\right)$ in $\mathrm{LB}$ medium plus spectinomycin, was then sprayed onto the surface of seeded agar plates. The plates were incubated at $28^{\circ} \mathrm{C}$ for an additional $18 \mathrm{~h}$. Antibiotic production was indicated by zones of clearing around the growth of Ecb11129(pCL1920).

Pigment production. Bacteria harbouring $\mathrm{pAKC} 880$ or

Table 1. Bacterial strains and plasmids

\begin{tabular}{|c|c|c|}
\hline Bacteria and plasmids & Relevant characteristics & Reference or source \\
\hline \multicolumn{3}{|l|}{ Strain } \\
\hline \multicolumn{3}{|c|}{ E. carotovora subsp. carotovora } \\
\hline 71 & Wild-type & Zink et al. (1984) \\
\hline 193 & Wild-type & Zink et al. (1984) \\
\hline AC5070 & $\mathrm{RsmA}^{-} \mathrm{Km}^{\mathrm{r}}$ & Chatterjee et al. (1995) \\
\hline SCC3193 & Wild-type & Pirhonen et al. (1993) \\
\hline SCRI193 & Wild-type & Salmond et al. (1986) \\
\hline \multicolumn{3}{|c|}{ E. carotovora subsp. atroseptica } \\
\hline Eca12 & Wild-type & Zink et al. (1984) \\
\hline \multicolumn{3}{|c|}{ E. carotovora subsp. betavasculorum } \\
\hline Ecb11129 & Wild-type & $\begin{array}{l}\text { J. E. Loper, Agricultural Research } \\
\text { Service, USDA, OR, USA }\end{array}$ \\
\hline \multicolumn{3}{|r|}{ (2) } \\
\hline EC183 & Wild-type & Chatterjee \& Brown (1981) \\
\hline CU156 & Wild-type & Laboratory collection \\
\hline \multicolumn{3}{|l|}{ E. herbicola } \\
\hline EH105 & Wild-type & Laboratory collection \\
\hline \multicolumn{3}{|l|}{ E. amylovora } \\
\hline E9 & Wild-type & Politis \& Goodman (1980) \\
\hline \multicolumn{3}{|l|}{ E. stewartii } \\
\hline DC283 & Wild-type & $\begin{array}{l}\text { D. L. Coplin, Ohio State } \\
\text { University, OH, USA }\end{array}$ \\
\hline \multicolumn{3}{|l|}{ Plasmid } \\
\hline pCL1920 & $\mathrm{Spc}^{\mathrm{r}} \mathrm{Sm}^{\mathrm{r}}$ & Lerner \& Inouye (1990) \\
\hline pAKC880 & $\mathrm{RsmA}^{+} \mathrm{Spc}^{\mathrm{r}}$ & Cui et al. (1995) \\
\hline pAKC882 & $\mathrm{pT} 7-r s m A, \mathrm{Ap}^{\mathrm{r}}$ & $\begin{array}{l}\text { PCR product of pAKC880 } \\
\text { cloned into pT7-7 (Tabor \& } \\
\text { Richardson, 1985) }\end{array}$ \\
\hline pAKC783 & pel-1 $1^{+} \mathrm{Ap}{ }^{\mathrm{r}}$ & Liu et al. (1994) \\
\hline
\end{tabular}


pCL1920 were patched on appropriate media supplemented with spectinomycin and incubated at $28^{\circ} \mathrm{C}$. Indigoidine production by E. chrysanthemi (CU156) was assayed on YGC agar (Chatterjee \& Brown, 1981) and carotenoid production by $E$. berbicola and E. stewartii was assayed on LB agar. Pigment production was examined visually after $24 \mathrm{~h}$ incubation.

Motility assay and detection of flagella. Bacterial cells harbouring pAKC880 or pCL1920 were stab-inoculated into soft $\mathrm{KB}$ agar supplemented with spectinomycin and incubated at $28{ }^{\circ} \mathrm{C}$. Motility of the bacteria was visually examined.

For detection of flagella, electron microscopy techniques were employed in which cells were negatively stained using $1 \%(\mathrm{v} / \mathrm{v})$ phosphotungstic acid and mounted on carbon-coated 200-mesh copper grids. Samples were visualized using transmission electron microscope model JEOL JEM 100B.

RNA analysis. Bacterial cultures were grown to a value of approximately 200 Klett units $\left(\mathrm{OD}_{600} 1.6\right)$ at $28^{\circ} \mathrm{C}$ in $\mathrm{LB}$ medium. The procedures for RNA isolation and Northern blot analysis described by Chatterjee et al. (1991) and Liu et al. (1993) were followed. Blots containing total RNA samples from Erwinia strains were hybridized using the 138 bp NdeI-Bg/II $\operatorname{rsm} A$ fragment of pAKC 882 or the 314 bp EcoRV-KpnI pel-1 fragment of $\mathrm{pAKC783}$ as a probe.

Test for EPS production. Bacteria harbouring pCL1920 or pAKC880 were patched on appropriate media supplemented with spectinomycin and incubated at $28^{\circ} \mathrm{C}$ for $24-48 \mathrm{~h}$. Cells of $E$. amylovora E9 and E. berbicola EH105 constructs were inoculated on nutrient agar supplemented with galactose $(1 \%$, $\mathrm{w} / \mathrm{v}$ ) and E. stewartii DC283 constructs were inoculated on minimal agar medium containing $1 \%(\mathrm{w} / \mathrm{v})$ sucrose. Production of EPS was indicated by a slimy and mucoid growth.

Elicitation of HR. Bacteria were grown overnight at $28^{\circ} \mathrm{C}$ on $\mathrm{LB}$ agar supplemented with spectinomycin or on $\mathrm{KB}$ agar. Cells were suspended in water or spectinomycin solution $\left(50 \mu \mathrm{g} \mathrm{ml}^{-1}\right)$ to a concentration of approximately $2 \times 10^{8}$ c.f.u. $\mathrm{ml}^{-1}$. Young fully expanded third and fourth leaves of 6-week-old plants of Nicotiana tobacum L. cv. Samsun were infiltrated with bacterial cell suspensions. Inoculated plants were incubated at $28^{\circ} \mathrm{C}$ for $24 \mathrm{~h}$ in a growth chamber with a $14 / 10 \mathrm{~h}$ daylight regime and visually monitored for reactions.

Pathogenicity assays on apple shoots. One-year-old branched Jonathan apple plants were transplanted into pots and maintained in a growth chamber at $28^{\circ} \mathrm{C}$ with a $14 / 10 \mathrm{~h}$ daylight regime. Four-week-old transplants with four to five side branches were used for the assay. The laminae of the first three to five fully expanded leaves were cut at the junction of the petioles. Cells of E. amylovora strain E9 harbouring pAKC880 or pCL1920, grown overnight on LB agar supplemented with spectinomycin, were suspended in spectinomycin solution $\left(50 \mu \mathrm{g} \mathrm{ml}^{-1}\right)$ to a concentration of approximately $2 \times 10^{8}$ c.f.u. $\mathrm{ml}^{-1}$. Aliquots $(5 \mu \mathrm{l})$ of cell suspensions were added to the cut surfaces and allowed to penetrate. This process was repeated until each petiole had absorbed a total of $30 \mu \mathrm{l}$ cell suspension. Inoculated plants were incubated for $24-48 \mathrm{~h}$ under the environmental conditions described above.

\section{RESULTS AND DISCUSSION}

\section{Occurrence of rsmA transcripts in Erwinia species}

$\operatorname{rsm} A$ homologues have been detected in many enterobacteria, including Erwinia species (Cui et al., 1995). To determine if $\operatorname{rsm} A$-like genes are normally expressed in (a)

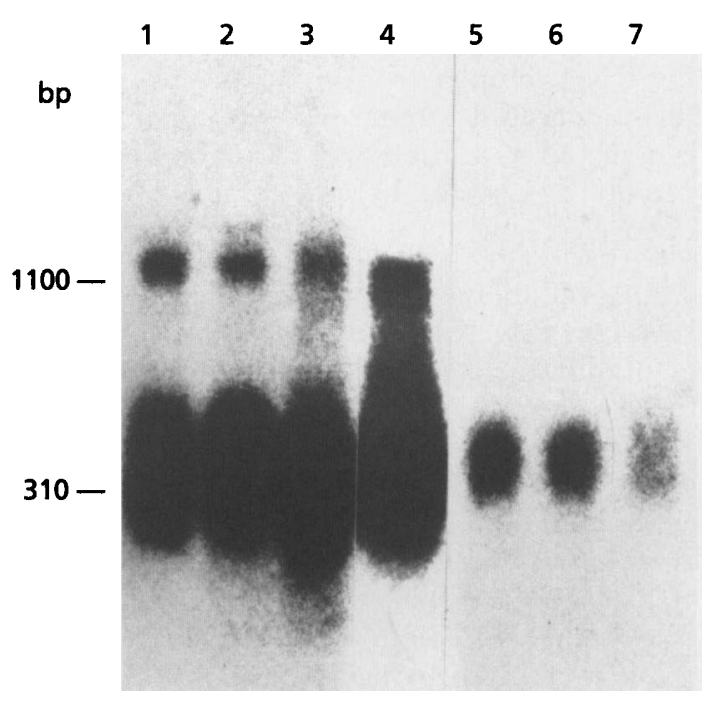

(b)

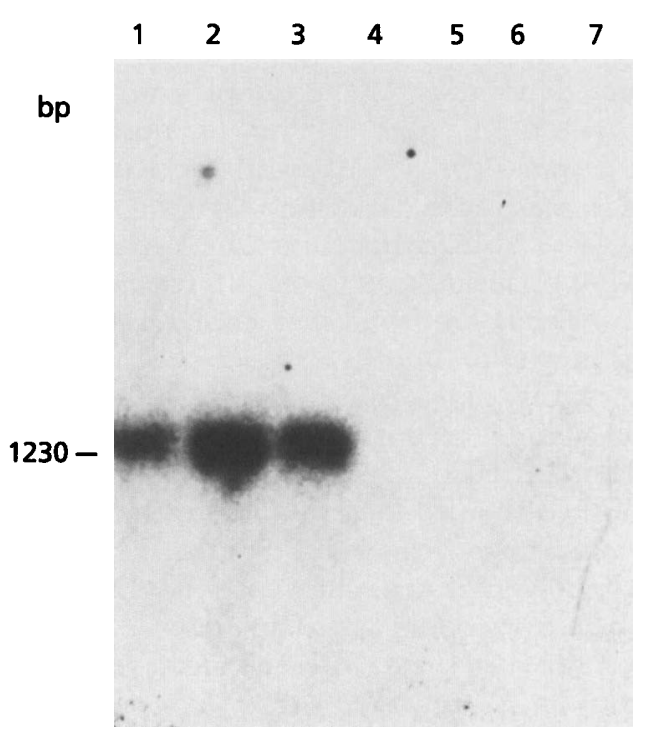

Fig. 1. Northern blot analysis of total RNA from Erwinia species using rsmA DNA (a) and pel-1 DNA (b) of E. carotovora subsp. carotovora 71 as probes. Lanes: 1, E. carotovora subsp. carotovora $71 ; 2$, E. carotovora subsp. atroseptica Eca12; 3, E. carotovora subsp. betavasculorum Ecb11129; 4, E. chrysanthemi EC183; 5, E. stewartii DC283; 6, E. amylovora E9; 7, E. herbicola EH105. Lanes 1-4 contained $10 \mu \mathrm{g}$ total RNA each; lanes 5-7 contained $20 \mu \mathrm{g}$ total RNA each.

these bacteria we conducted Northern analysis using the $\operatorname{rsm} A$ DNA of E. carotovora subsp. carotovora as the probe. The data presented in Fig. 1(a) show that $\operatorname{rsm} A$ transcripts were present in the wild-type strains of $E$. amylovora, $E$. carotovora subsp. atroseptica, E. carotovora subsp. betavasculorum, E. carotovora subsp. carotovora, E. chrysanthemi, $E$. berbicola and $E$. stewartii. A duplicate blot was hybridized under similar conditions with pel-1 DNA of $E$. 
carotovora subsp. carotovora strain 71 (Liu et al., 1994). In the latter case, we detected signals with the RNA samples from strains belonging to E. carotovora subspecies but not with the RNA samples from other Erwinia species (Fig. 1b). This observation strengthens our conclusion that the signals detected with the $\operatorname{rsm} A$ DNA as the probe (Fig. 1a) were due to specific hybridization with the cognate mRNA species.

Transcripts of about $310 \mathrm{bp}$ hybridizing with the $E$. carotovora $\operatorname{rsm} A$ were detected in all bacterial species tested. In addition, another larger transcript hybridized with the $\operatorname{rm} A$ probe in soft-rotting Erwinia species, but not in E. berbicola and E. stewartii (Fig. 1a). We should note that the larger transcript was observed with $E$. amylovora samples only upon longer exposure (i.e. $7 \mathrm{~d}$ instead of $2 \mathrm{~d}$ ) of the X-ray film (data not shown). The low intensity of the signal of this transcript could be due to the use of a heterologous probe. We are currently testing this hypothesis by using E. amylovora rsm $A$ DNA as the probe.

These findings suggest that $\operatorname{rsm} A$ may be organized as a multicistronic operon. Recent observations in our laboratory with $E$. carotovora subsp. carotovora strain 71 support this hypothesis. While the plasmid carrying the $183 \mathrm{bp}$ rsm $A$ ORF plus $245 \mathrm{bp}$ of upstream DNA produced a transcript of $310 \mathrm{bp}$ in the $\mathrm{RsmA}^{-}$mutant AC5070 (Cui et al., 1995), a plasmid carrying this ORF and additional $(>2 \mathrm{~kb})$ downstream DNA yielded a transcript of $1100 \mathrm{bp}$ in addition to the $310 \mathrm{bp}$ transcript (data not shown). The latter profile was similar to that found in the wild-type strains of $E$. carotovora subspecies and $E$. chrysantbemi (Fig. 1a). The presence of a mini-Tn5 transposon within the upstream DNA sequences of the rsm A ORF in AC5070 (Chatterjee et al., 1995; Cui et al., 1995) abolished the production of both the 310 and the 1100 bp transcripts. Analysis by Southern hybridization of appropriately digested chromosomal DNA and an $\mathrm{RsmA}^{+}$cosmid carrying approximately $22 \mathrm{~kb}$ chromosomal DNA revealed that $r s m A$ sequences were present in a single copy in E. carotovora subsp. carotovora strain 71 . Since there is no evidence of gene duplication, the existence of two species of $r s m A$ transcripts might be due to the utilization of different start and termination sites. Additional studies are clearly needed to understand the mechanism, as well as the physiological significance, of the production of these transcripts.

\section{Effect of rsmA on antibiotic production in $E$. carotovora subsp. betavasculorum}

E. carotovora subsp. betavasculorum strains are known to produce antibiotics that inhibit $E$. carotovora subsp. carotovora (Axelrood et al., 1988; Costa \& Loper, 1994). The suppression of HSL synthesis and extracellular enzyme production in E. carotovora subsp. betavasculorum by $r s m A$ of E. carotovora subsp. carotovora strain 71 (Cui $e t$ al., 1995) prompted us to determine if $\operatorname{rsm} A$ also had an effect on antibiotic production. In preliminary trials we noted that E. carotovora subsp. betavasculorum strain
Ecb11129 produced an antibiotic(s) which inhibited the growth of E. carotovora subsp. carotovora strains 71, 193, SCRI193 and SCC3193. To test the effect of $r \mathrm{sm} A$, cells of Ecb11129 harbouring pAKC880 or pCL1920 were grown on NAG agar plus spectinomycin for $48 \mathrm{~h}$ and then oversprayed with cells of E. carotovora subsp. carotovora strain 193 harbouring pCL1920. After $18 \mathrm{~h}$ incubation, a zone of clearing was observed around the growth of Ecb11129(pCL1920). By contrast, no clear zone was detected around the growth of Ecb11129(pAKC880), indicating a severe repression of antibiotic production. By extrapolating from our previous observation that multiple copies of $r s m A$ suppressed HSL production in Ecb11129 (Cui et al., 1995), we suggest that the pleiotropic effect of $\operatorname{rsm} A$ on the production of antibiotic and extracellular enzymes, as well as on pathogenicity, is due to the repression of the cell density (quorum) sensing signal. In this context, we should note that the biosynthesis of a $\beta$ lactam antibiotic, 1-carbapen-2-em-3-carboxylic acid, is controlled by HSL in E. carotovora subsp. carotovora (Bainton et al., 1992; Salmond et al., 1995), a bacterium closely related to $E$. carotovora subsp. betavasculorum.

\section{Effect of rsmA on pigment production}

The $r s m A$ plasmid pAKC880 suppressed the production of carotenoid pigment in E. herbicola strain EH105 and in E. stewartii strain DC283 and indigoidine pigment in E. chrysanthemi strain CU156 (data not shown). The genes that regulate the production of these pigments have not yet been identified, with the exception of indigoidine. In that case, a negative regulator gene, pec $S$, was found to control pectinases as well as the pigment in E. chrysanthemi strain 3937 (Reverchon et al., 1994). Since $r s m A$ and pecS genes do not share sequence homology and $\operatorname{rsm} A$ homologues have been detected in E. chrysanthemi (Cui et al., 1995), we postulate that these genes control indigoidine production by different mechanisms.

\section{rsmA suppresses EPS production}

The data of Cui et al. (1995) revealed that $r$ sm $A$ suppressed glycogen accumulation in $E$. coli $\mathrm{B}$, suggesting that it was also responsible for repression of EPS production in Erwinia species. To test this possibility, pCL1920 or pAKC880 was transferred into E. amylovora strain E9, E. berbicola strain EH105, and E. stewartii strain DC283, after which the drug-resistant transformants were scored for EPS production on agar media. E. amylovora E9(pCL1920) produced copious amounts of polysaccharide as indicated by glistening, extremely mucoid growth. By contrast, the growth of bacteria harbouring pAKC 880 mostly remained non-mucoid. Similar results were found with other bacterial strains. Since EPS production in E. amylovora and E. stewartii is controlled by the rcs genes (Coleman et al., 1990; Roberts \& Coleman, 1991; Leigh \& Coplin, 1992; Bernhard et al., 1990; Vanneste, 1995), it would be of interest to determine if $r s m A$ affects polysaccharide production by modulating the expression of these genes. 


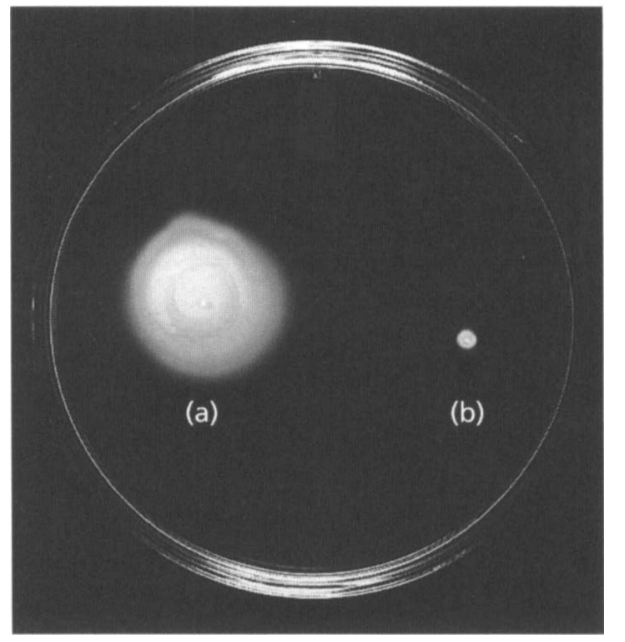

Fig. 2. Inhibition of motility of $E$. carotovora subsp. carotovora SCC3193 by rsmA. SCC3193(pCL1920) (a) and SCC3193(pAKC880) (b) were stab-inoculated into soft KB agar supplemented with spectinomycin using a straight needle and incubated at $28^{\circ} \mathrm{C}$ for $24 \mathrm{~h}$.

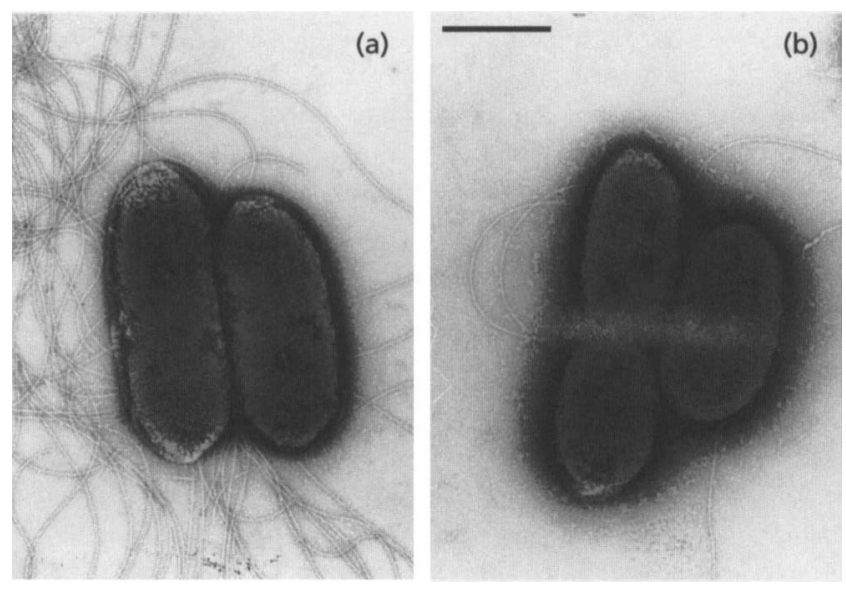

Fig. 3. Electron microscopic examination of flagella of $E$. carotovora subsp. carotovora SCC3193 harbouring pCL1920 (a) and pAKC880 (b). Bacterial cells were harvested from soft KB agar, stained with $1 \%(\mathrm{v} / \mathrm{v})$ phosphotungstic acid, and mounted on 200-mesh carbon-coated grid. Samples were examined using a transmission electron microscope model JEOL JEM 100B. Bar, $1 \mu \mathrm{m}$.

\section{Inhibition of motility by rsmA}

Most Erwinia species and other enterobacteria are motile, as indicated by the radial diffusion of growth beyond the point of inoculation on soft agar. The occurrence of twitching type motility has been documented for a number of enterobacterial species (see Harshey, 1994, for a review). Indeed, E. carotovora subsp. carotovora strain SCC3193 swarms extensively, covering the entire $10 \mathrm{~cm}$ agar surface of a standard Petri plate upon incubation for $36-48 \mathrm{~h}$ at $28^{\circ} \mathrm{C}$ (data not shown). As shown in Fig. 2, while cells of SCC3193 harbouring pCL1920 were motile, those harbouring pAKC880 were non-motile. Similarly, motility was suppressed by pAKC880 in E. amylovora, E. rhapontici and other Erwinia species (A. K. Chatterjee, unpublished results).

To ascertain if the suppression of motility by $\operatorname{rsm} A$ was due to the inhibition of flagella formation, we examined negatively stained bacterial cells by transmission electron microscopy. As shown in Fig. 3, while cells of strain SCC3193(pCL1920) possessed numerous flagella, those of SCC3193(pAKC880) either were non-flagellated or at most contained one to two flagella. Thus, in addition to suppressing various secondary metabolic systems (see above), $\operatorname{sm} A$ also causes a marked reduction in flagellum formation. Since $r s m A$ suppressed motility in most Erwinia species in addition to E. carotovora subsp. carotovora, it appears that regulation of flagellum formation is a generalized function of $r m A$.

\section{Effect of rsmA on the elicitation of HR}

When Gram-negative phytopathogenic bacteria are infiltrated into non-host plants, they elicit rapid cell death followed by a drop in the viability of bacterial cells. The necrogenic reaction, also generally known as $\mathrm{HR}$ (Willis $e t$ al., 1991; Goodman \& Novacky, 1994), remains limited to the area infiltrated with the bacterial suspension. $E$. amylovora strains are known to elicit $\mathrm{HR}$ in tobacco leaves (Klement \& Goodman, 1966), and the genes that elicit $\mathrm{HR}$, the $b r p$ genes, as well as an elicitor of HR have been isolated (Beer et al., 1991; Wei et al., 1992a, b; Baker et al., 1993). To test if $r s m A$ affected the ability to elicit HR, we compared the responses with $E$. amylovora strain E9 harbouring pCL1920 or pAKC880. The results clearly demonstrated that $\mathrm{E} 9$ (pCL1920) elicited typical HR in tobacco leaves, whereas $\mathrm{E} 9(\mathrm{pAKC} 880)$ failed to elicit any discernible response under similar conditions (data not shown). The molecular basis for this differential response is not yet known. A plausible explanation is that the $r \operatorname{sm} A$ product suppresses the expression of one or more $b r p$ genes.

\section{Attenuation of pathogenicity in E. amylovora by rsmA}

Several studies have established that an EPS, also known as amylovoran, is required for pathogenicity of $E$. amylovora (Bugert \& Geider, 1995, and references cited therein). The suppression of polysaccharide production in E. amylovora strain E9 by E. carotovora subsp. carotovora $\operatorname{rsm} A$ (see above) raised the possibility that virulence of strain E9 could also be affected by multiple copies of this gene. The results of an apple shoot assay (data not shown) showed that $\mathrm{E}$ 9(pCL1920) caused tip bending and wilting of the apple shoot, typical responses elicited by a virulent fire-blight pathogen (Van der Zwet \& Beer, 1992). By contrast, these symptoms were not elicited by $\mathrm{E} 9$ (pAKC880). Whether this repression was due to the lack of polysaccharide production or repression of other disease-specific genes or the $b r p$ cluster awaits clarification.

In summary, we have shown that: (i) $r s m A$ homologues occur in all Erwinia strains tested (Cui et al., 1995); (ii) $\operatorname{rsm} A$ or $\operatorname{rsm} A$-like genes are normally expressed in 
Erwinia species; (iii) the E. carotovora $\operatorname{rsm} A$ locus suppresses an array of secondary metabolic systems in several Erwinia species; and (iv) multiple copies of $\operatorname{rsm} A$ affect the induction of HR by E. amylovora and pathogenicity of various Erwinia species (Cui et al., 1995; and this report). Moreover, $r \operatorname{sm} A$ suppresses the levels of HSL in most Erwinia species tested and substantially reduces the levels of transcripts of $h s l I$, a homologue of carI (Swift et al., 1993) and expI (Pirhonen et al., 1993), required for HSL production in E. carotovora subsp. carotovora strain 71 (Chatterjee et al., 1995; Cui et al., 1995).

The mechanism by which $r$ sm $A$ regulates these responses in so many different bacteria is not yet understood. However, in a recent report, Liu et al. (1995) have proposed that the product of the negative regulator gene csr $A$ of E. coli binds to mRNA of the target gene, $g l g C$, accelerating the degradation of the transcripts. Thus, in this model CsrA is proposed to regulate expression of the target gene by shortening the half-life of its transcript. As stated elsewhere (Cui et al., 1995), RsmA and CsrA sequences are highly similar and both proteins possess the putative RNA-binding motif. Therefore, we suggest that RsmA, like CsrA, controls gene expression by causing a rapid decay of mRNA. It remains to be determined if RsmA acts directly on the transcripts of pel, peh, cel, prt, fla and an array of other genes or if it affects the expression of these genes indirectly by accelerating the decay of transcripts of one or more global transcriptional factors. Examples of such putative factors may include specialized sigma factors (Givskov et al., 1995; Hengge-Aronis, 1993; Kolter et al., 1993; Macnab, 1992; Xiao et al., 1994), the products of aep genes (Liu et al., 1993; Murata et al., 1991, 1994) and HSL or its structural analogues and other components of the cell density sensing signalling system (Fuqua et al., 1994; McGowan et al., 1995; Salmond et al., 1995; Swift et al., 1994), now known to control various secondary metabolites.

\section{ACKNOWLEDGEMENTS}

We thank A. J. Novacky and D. Pinkerton for photography, S. Pike for the gift of tobacco plants, and D. L. Coplin, J. E. Loper, A. J. Novacky, E. T. Palva and G. P. C. Salmond for bacterial strains. We also thank J. E. Bourque and J. E. Schoelz for reviewing the manuscript. This research was supported by the National Science Foundation (grant DBM-9018733) and the Food for 21st Century Program of the University of Missouri. This article is journal series 12353 of the Missouri Agricultural Experiment Station.

\section{REFERENCES}

Axelrood, P. E., Rella, M. \& Schroth, M. N. (1988). Role of antibiosis in competition of Erwinia strains in potato infection courts. Appl Environ Microbiol 54, 1222-1229.

Bainton, N. J., Stead, P., Chhabra, S. R., Bycroft, B. W., Salmond, G. P. C., Stewart, G. S. A. B. \& Williams, P. (1992). N-(3-Oxohexanoyl)-L-homoserine lactone regulates carbapenem antibiotic production in Erwinia carotovora. Biocbem J 288, 997-1004.

Baker, C. J., Orlandi, E. W. \& Mock, N. M. (1993). Harpin, an elicitor of the hypersensitive response in tobacco caused by Erwinia amylovora, elicits active oxygen production in suspension cells. Plant Physiol 102, 1341-1344.
Barras, F., Thurn, K. K. \& Chatterjee, A. K. (1987). Resolution of four pectate lyase structural genes of Erwinia chrysanthemi (EC16) and characterization of the enzymes produced in Escherichia coli. Mol E Gen Genet 209, 319-325.

Barras, F., van Gijsegem, F. \& Chatterjee, A. K. (1994). Extracellular enzymes and pathogenesis of soft-rot Erwinia. Annu Rev Pbytopathol 32, 201-234.

Beck von Bodman, S. \& Farrand, S. K. (1995). Capsular polysaccharide biosynthesis and pathogenicity in Erwinia stewartii require induction by an $\mathrm{N}$-acylhomoserine lactone autoinducer. $J$ Bacteriol 177, 5000-5008.

Beer, S. V., Bauer, D. W., Jiang, X. H., Laby, R. J., Sneath, B. J., Wei, Z. M., Wilcox, D. A. \& Zumoff, C. H. (1991). The brp gene cluster of Erwinia amylovora. In Proceedings of the 5th International Symposium on Molecular Genetic Plant-Microbe Interactions, pp. 53-60. Edited by H. Hennecke \& D. P. S. Verma. The Netherlands: Kluwer Academic Publishers.

Bernhard, F., Poetter, K., Geider, K. \& Coplin, D. L. (1990). The $\operatorname{rcs} A$ gene from Erwinia amylovora: identification, nucleotide sequence, and regulation of exopolysaccharide biosynthesis. Mol Plant-Microbe Interact 3, 429-437.

Bugert, P. \& Geider, K. (1995). Molecular analysis of the ams operon required for exopolysaccharide synthesis of Erwinia amylovora. Mol Microbiol 15, 917-933.

Chatterjee, A. K. (1980). Acceptance by Erwinia spp. of R plasmid R68.45 and its ability to mobilize the chromosome of Erwinia chrysanthemi. J Bacteriol 142, 111-119.

Chatterjee, A. K. \& Brown, M. A. (1981). Chromosomal location of a gene (idg) that specifies production of the blue pigment indigoidine in Erwinia cbrysanthemi. Curr Microbiol 6, 269-273.

Chatterjee, A. K. \& Vidaver, A. K. (1986). Genetics of pathogenicity factors: application to phytopathogenic bacteria. In Advances in Plant Patbology, vol. 4, pp. 1-224. Edited by D. S. Ingram \& P. H. Williams. London: Academic Press.

Chatterjee, A., McEvoy, J. L., Chambost, J.P., Blasco, F. \& Chatterjee, A. K. (1991). Nucleotide sequence and molecular characterization of $p n l A$, the structural gene for damage-inducible pectin lyase of Erwinia carotovora subsp. carotovora 71. J Bacteriol 173, 1765-1769.

Chatterjee, A., Cui, Y. Y., Liu, Y., Dumenyo, C. K. \& Chatterjee, A. K. (1995). Inactivation of $\operatorname{rsm} A$ leads to overproduction of extracellular pectinases, cellulases, and proteases in Erwinia carotovora subsp. carotovora in the absence of the starvation/cell densitysensing signal, N-(3-oxohexanoyl)-L-homoserine lactone. Appl Environ Microbiol 61, 1959-1967.

Coleman, M., Pearce, R., Hitchin, E., Busfield, F., Mansfield, J. W. \& Roberts, I. S. (1990). Molecular cloning, expression and nucleotide sequence of the $\operatorname{rcs} A$ gene of Erwinia amylovora, encoding a positive regulator of capsule expression: evidence for a family of related capsule activator proteins. J Gen Microbiol 136, 1799-1806.

Collmer, A. \& Keen, N. T. (1986). The role of pectic enzymes in plant pathogenesis. Annu Rev Phytopathol 24, 383-409.

Costa, J. M. \& Loper, J. E. (1994). Derivation of mutants of Erwinia carotovora subsp. betavasculorum deficient in export of pectolytic enzymes with potential for biological control of potato soft rot. Appl Environ Microbiol 60, 2278-2285.

Cui, Y. Y., Chatterjee, A., Liu, Y., Dumenyo, C. K. \& Chatterjee, A. K. (1995). Identification of a global repressor gene, $\operatorname{rm} A$, of Erwinia carotovora subsp. carotovora that controls extracellular enzymes, $N$-(3-oxohexanoyl)-L-homoserine lactone and pathogenicity in soft-rotting Erwinia. J Bacteriol 177, 5108-5115.

Fuqua, W. C., Winans, S. C. \& Greenberg, E. P. (1994). Quorum 
sensing in bacteria : the LuxR-LuxI family of cell density-responsive transcriptional regulators. J Bacteriol 176, 269-275.

Givskov, M., Eberl, L., Christiansen, G., Benedik, M. J. \& Molin, S. (1995). Induction of phospholipase and flagellar synthesis in Serratia liquefaciens is controlled by expression of the flagellar master operon $A b D$. Mol Microbiol 15, 445-454.

Goodman, R. N. \& Novacky, A. J. (1994). The Hypersensitive Reaction in Plants to Pathogens, a Resistance Pbenomenon, pp. 1-244. St Paul, MN: American Phytopathological Society Press.

Harshey, R. M. (1994). Bees aren't the only ones: swarming in Gram-negative bacteria. Mol Microbiol 13, 389-394.

Hengge-Aronis, R. (1993). Survival of hunger and stress: the role of $r$ o $S$ in early stationary phase gene regulation in E. coli. Cell 72, $165-168$

Jones, S., Yu, B., Bainton, N. J., Birdsall, M., Bycroft, B. W., Chhabra, S. R., Cox, A. J. R., Golby, P., Reeves, P. J., Stephens, S., Winson, M. K., Salmond, G. P. C., Stewart, G. S. A. B. \& Williams, P. (1993). The lux autoinducer regulates the production of exoenzyme virulence determinants in Erwinia carotovora and Pseudomonas aeruginosa. EMBO J 12, 2477-2482.

Klement, Z. \& Goodman, R. N. (1966). Hypersensitive reaction induced in apple shoots by an avirulent form of Erwinia amylovora. Acta Pbytopatbol Acad Sci Hung 1, 177-184.

Kolter, R., Sigele, D. A. \& Tormo, A. (1993). The stationary phase of the bacterial life cycle. Annu Rev Microbiol 47, 855-874.

Kotoujansky, A. (1987). Molecular genetics of pathogenesis by soft-rot Erwinias. Annu Rev Phytopatbol 25, 405-430

Leigh, J. A. \& Coplin, D. L. (1992). Exopolysaccharides in plant bacterial interactions. Annu Rev Microbiol 46, 307-346.

Lerner, C. G. \& Inouye, M. (1990). Low copy number plasmids for regulated low-level expression of cloned genes in Escherichia coli with blue/white insert screening capability. Nucleic Acids Res 18, 4631.

Liu, Y., Murata, H., Chatterjee, A. \& Chatterjee, A. K. (1993). Characterization of a novel regulatory gene aep $A$ that controls extracellular enzyme production in the phytopathogenic bacterium Erwinia carotovora subsp. carotovora. Mol Plant-Microbe Interact 6, 299-308.

Liu, Y., Chatterjee, A. \& Chatterjee, A. K. (1994). Nucleotide sequence and expression of a novel pectate lyase gene (pel-3) and a closely linked endopolygalacturonase gene (peb-1) of Erwinia carotovora subsp. carotovora 71. Appl Environ Microbiol 60, 2545-2552.

Liu, Y. M., Yang, H. \& Romeo, T. (1995). The product of the pleiotropic Escherichia coli gene csr $A$ modulates glycogen biosynthesis via effects on mRNA stability. $J$ Bacteriol 177, 2663-2672.

Macnab, R. M. (1992). Genetics and biogenesis of bacterial flagella. Annu Rev Genet 26, 131-158.

McGowan, S., Sebaihia, M., Jones, S., Yu, B., Bainton, N., Chan, P. F., Bycroft, B., Stewart, G. S. A. B., Williams, P. \& Salmond, G. P. C. (1995). Carbapenem antibiotic production in Erwinia carotovora is regulated by CarR, a homologue of the LuxR transcriptional activator. Microbiology 141, 541-550.

Murata, H., Fons, M., Chatterjee, A., Collmer, A. \& Chatterjee, A. K. (1990). Characterization of transposon insertion $\mathrm{Out}^{-}$mutants of Erwinia carotovora subsp. carotovora defective in enzyme export and of a DNA segment that complements out mutations in E. carotovora subsp. carotovora, E. carotovora subsp. atroseptica, and Erwinia chrysanthemi. J Bacteriol 172, 2970-2978.

Murata, H., McEvoy, J. L., Chatterjee, A., Collmer, A. \& Chatterjee, A. K. (1991). Molecular cloning of an aep $A$ gene that activates production of extracellular pectolytic, cellulolytic and proteolytic enzymes in Erwinia carotovora subsp. carotovora. Mol Plant-Microbe Interact 4, 239-246.

Murata, H., Chatterjee, A., Liu, Y. \& Chatterjee, A. K. (1994). Regulation of the production of extracellular pectinase, cellulase, and protease in the soft rot bacterium Erwinia carotovora subsp. carotovora: evidence that aepH of E. carotovora subsp. carotovora 71 activates gene expression in $E$. carotovora subsp. carotovora, $E$. carotovora subsp. atroseptica, and Escherichia coli. Appl Environ Microbiol 60, 3150-3159.

Pirhonen, M., Flego, D., Heikinheimo, R. \& Palva, E. T. (1993). A small diffusible signal molecule is responsible for the global control of virulence and exoenzyme production in the plant pathogen Erwinia carotovora. EMBO J 12, 2467-2476.

Politis, D. J. \& Goodman, R. N. (1980). Fine structure of extracellular polysaccharide of Erwinia amylovora. Appl Environ Microbiol 40, 596-607.

Reverchon, S., Nasser, W. \& Robert-Baudouy, J. (1994). pecS: a locus controlling pectinase, cellulase and blue pigment production in Erwinia chrysantbemi. Mol Microbiol 11, 1127-1139.

Roberts, I. S. \& Coleman, M. J. (1991). The virulence of Erwinia amylovora: molecular genetic perspectives. $J$ Gen Microbiol 137, 1453-1457.

Salmond, G. P. C., Hinton, J. C. D., Gill, D. R. \& Perombelon, M. C. M. (1986). Transposon mutagenesis of Erwinia using phage $\lambda$ vectors. Mol \& Gen Genet 203, 524-528.

Salmond, G. P. C., Bycroft, B. W., Stewart, G. S. A. B. \& Williams, P. (1995). The bacterial 'enigma': cracking the code of cell-cell communication. Mol Microbiol 16, 615-624.

Starr, M. P. (1983). The genus Erwinia. In The Prokaryotes, vol. 2, pp. 1260-1271. Edited by M. P. Starr, H. Stolp, H. G. Trüper, A. Balows \& H. G. Schlegel. Berlin: Springer-Verlag.

Swift, S., Winson, M. K., Chan, P. F., Bainton, N. J., Birdsall, M., Reeves, P. J., Rees, C. E. D., Chhabra, S. R., Hill, P. J., Throup, J. P., Bycroft, B. W., Salmond, G. P. C., Williams, P. \& Stewart, G. S. A. B. (1993). A novel strategy for the isolation of luxI homologues: evidence for the widespread distribution of a LuxR:LuxI superfamily in enteric bacteria. Mol Microbiol 10, 511-520.

Swift, S., Bainton, N. J. \& Winson, M. K. (1994). Gram-negative bacterial communication by $\mathrm{N}$-acyl homoserine lactones: a universal language? Trends Microbiol 2, 193-198.

Tabor, S. \& Richardson, C. C. (1985). A bacteriophage T7 RNA polymerase/promoter system for controlled exclusive expression of specific genes. Proc Natl Acad Sci US A 82, 1047-1078.

Van der Zwet, T. \& Beer, S. V. (1992). Fire Blight-its Nature, Prevention, and Control. A Practical Guide to Integrated Disease Management. USDA Agriculture Information Bulletin Number 631.

Vanneste, J. L. (1995). Erwinia amylovora. In Patbogenesis and Host Specificity in Plant Diseases: Histopathological, Biochemical, Genetic and Molecular Bases, vol. 1 Prokaryotes, pp. 21-41. Edited by U. S. Singh, R. P. Singh \& K. Kohmoto. Oxford, London: Pergamon Press.

Wei, Z. M., Laby, R. J., Zumoff, C. H., Bauer, D. W., He, S. Y., Collmer, A. \& Beer, S. V. (1992a). Harpin, elicitor of the hypersensitive response produced by the plant pathogen Erwinia amylovora. Science 257, 85-88.

Wei, Z. M., Sneath, B. J. \& Beer, S. V. (1992b). Expression of Erwinia amylovora brp genes in response to environmental stimuli. $J$ Bacteriol 174, 1875-1882.

Williams, P., Bainton, N. J., Swift, S., Chhabra, S. R., Winson, M. K., Stewart, G. S. A. B., Salmond, G. P. C. \& Bycroft, B. W. (1992). Small molecule-mediated density-dependent control of gene expression in prokaryotes: bioluminescence and the biosynthesis of carbapenem antibiotics. FEMS Microbiol Lett 100, 161-168. 
Willis, D. K., Rich, J. J. \& Hrabak, E. M. (1991). $b r p$ genes of phytopathogenic bacteria. Mol Plant-Microbe Interact 4, 132-138.

Xiao, Y., Heu, S., Yi, J., Lu, Y. \& Hutcheson, S. W. (1994). Identification of a putative alternate sigma factor and characterization of a multicomponent regulatory cascade controlling the expression of Pseudomonas syringae pv. syringae Pss61 hrp and $\mathrm{brm} A$ genes. J Bacteriol 176, 1025-1036.
Zink, R. T., Kemble, R. J. \& Chatterjee, A. K. (1984). Transposon Tn 5 mutagenesis in Erwinia carotovora subsp. carotovora and $E$. carotovora subsp. atroseptica. J Bacteriol 157, 809-814.

Received 11 July 1995; revised 15 September 1995; accepted 21 September 1995. 